\title{
THE ROLE OF OPEN INNOVATION INTERMEDIARIES IN ENTREPRENEURIAL ECOSYSTEMS DESIGN
}

\author{
C.N. Ngongoni ${ }^{1 * \#}$, S.S. Grobbelaar ${ }^{1,2}$ \& C.S.L. Schutte ${ }^{1,2}$
}

\section{ARTICLE INFO}

\section{Article details}

Presented at the $28^{\text {th }}$ annual conference of the Southern African Institute for Industrial Engineering (SAIIE), held from 25-27 October 2017 in Vanderbijlpark, South Africa

Available online

22 Nov 2017

\section{Contact details}

Corresponding author

chipo.ngongoni@gmail.com

\section{Author affiliations}

1 Department of Industrial

Engineering, University of

Stellenbosch, South Africa

2 DST-NRF Centre of Excellence in Scientometrics and Science, Technology and Innovation Policy (SciSTIP), University of Stellenbosch, South Africa

\# $\quad$ The author was enrolled for a PhD (Industrial Engineering) degree in the Department of Industrial Engineering, University of Stellenbosch

DOI

http://dx.doi.org/10.7166/28-3-1839

\section{ABSTRACT}

Unemployment levels in South Africa have reached astronomical levels. This has spurred the government to fund entrepreneurship initiatives such as the Enterprise and Supplier Development programmes. Thus it is vital to enable and create entrepreneurial ecosystems that attract, cultivate, and sustain entrepreneurs. This paper explores how entrepreneurial firms use external actors for value creation in an entrepreneurial ecosystem through intermediaries. The focus is on how an intermediary organisation can facilitate value co-creation. The authors present the results and findings from a case study of the Oslo Cancer Cluster incubator in Norway, and relate these findings to ecosystems management and design.

\section{OPSOMMING}

Werkloosheidsvlakke in Suid-Afrika het astronomies verhoog. Dit het die regering aangespoor om entrepreneurskap inisiatiewe soos onderneming en verskaffer ontwikkelingsprogramme te finansier. Daarom is dit van kardinale belang om entrepreneurskap ekosisteme te skep wat entrepreneurs lok, kweek en ondersteun. Hierdie artikel ondersoek hoe entrepreneuriese maatskappye eksterne akteurs deur middel van tussengangers vir waardeskepping gebruik in 'n entrepreneuriese ekosisteem. Die fokus van die artikel is op hoe 'n tussenganger organisasie waarde mede-skepping kan fasiliteer. Die skrywers beskryf huidige resultate en bevindinge van 'n gevallestudie van die Oslo Kanker Samewerkingsgroep broeikas in Noorweë, en lei hieruit bevindinge vir ekosisteem bestuur en ontwerp af.

\section{INTRODUCTION AND BACKGROUND}

The impact of the operating environment on a firm's innovativeness and survival is a question that has been addressed in research for quite some time now. This has been explored through areas of inquiry such as cluster theory, agglomeration economies, and regional innovation studies [1], [2]. Studies in these areas address the role of proximity and location of firms within the same industry, and how they compete and cooperate. Other theories and frameworks such as causation, effectuation, and open innovation attempt to address causal firm behaviour that promotes innovativeness [3]-[5]. Although these streams have enhanced insight into the dynamics surrounding entrepreneurial activities and dynamics, it has been increasingly noted that the underlying forces and actors in regions of high entrepreneurial activity cannot be studied independently [6]-[9]. Therefore, the entrepreneurial ecosystem (EES) construct has become a useful framework for analysing the dynamics among systems actors.

Entrepreneurial ecosystems encompass the organisations, institutions, and individuals that, apart from the entrepreneur, either promote or inhibit entrepreneurship [10], [11]. Construction of these ecosystems is a costly process, as it requires the development of absorptive capacities in industries, firms, and government [12]. Policymakers have tried to replicate successful ecosystems such as Silicon Valley, but without the expected success. This can be attributed to the fact that ecosystem 
design, construction, and implementation is not a one-size-fits-all process. Policy-makers need to understand the cultural dynamics and behavioural characteristics in order to create successful and mutually beneficial entrepreneurial ecosystems [7], [8], [13].

Because ecosystems research is mainly concerned with the definition of ecosystem boundaries and coordination, there is still a need to consider the relational aspects among the actors [6], [14], [15], and how these assist in the evolution of the ecosystem. Moreover, an in-depth understanding of how, when, and why different ecosystem actors interact with each other cultivates sustainable entrepreneurship. South Africa has seen the value of supporting entrepreneurial ecosystems, as shown by the influx of entrepreneurial start-up funds and platforms that promote collaboration between entrepreneurs and larger organisations. Examples of these platforms are the Open Innovation Exchange ${ }^{1}$ in Gauteng and Connect and Solve ${ }^{2}$ in East London. These initiatives are meant to aid in the creation of viable ecosystems; but for the initiatives to be successful, the value created by the actors in the ecosystem should be appropriated by the intended audience [6].

This study stems from the view that, for substantial value to be created and appropriated in an ecosystem, the actors need to interact in various ways [15], [16]. It builds on the perspective that, in an ecosystem, collective value co-creation is not something that happens automatically, but needs to be facilitated [17]. This was achieved through an analysis of the roles an intermediary (such as an incubator) exhibits, and of the actors' interactions that promote co-creation in the ecosystem [18]. The approach used was to consider aspects of the open innovation paradigm to explore the types of interactions and entrepreneurial firm behaviours. The aim was to investigate how an intermediary assists entrepreneurial firms in their value-creation process through engaging with multiple stakeholders to substantiate the ecosystem and to ensure the competitiveness and survival of the firms.

In this study, 'value' is understood as all the actions that are aimed at increasing the worth of a firm; and 'value co-creation' is defined as the process that allows various actors to create value through interaction and the exchange of tangible and intangible resources ${ }^{3}$.

To this end, the study considers this question:

\section{How does an intermediary assist in the value creation process for start-ups in an entrepreneurial ecosystem?}

These research sub-questions follow:

- Is intermediation necessary in an entrepreneurial ecosystem?

- What intermediary role is of importance to the start-ups to promote value-creation in an entrepreneurial ecosystem?

- What interaction processes aid value-creation between actors and the intermediary in an entrepreneurial ecosystem?

To address these questions, the authors will show how the literature themes of entrepreneurial ecosystems and innovation intermediaries assist in the value creation process of the firms. This is done in order to offer insight into how an entity such as the government can play an active role in entrepreneurship by offering intermediation platforms.

\section{A BRIEF LITERATURE REVIEW}

\subsection{Open innovation intermediaries and entrepreneurial ecosystems}

An entrepreneurial ecosystem (EES) "consists of a set of individual elements - such as leadership, culture, capital markets, and open-minded customers - that combine in complex ways" [11].

Through their analysis of ecosystems research, Autio and Thomas [6] pointed out that an ecosystem has a central hub, platform, or focal firm. Although their focus was particularly on innovation

http://www.theinnovationhub.com/opportunities/openix-5

http://connectandsolve.co.za/index.php?page=about

http://www.businessdictionary.com/definition/value-creation.html\#ixzz48ypoJAOD 
ecosystems, the same structure can be applied to entrepreneurial ecosystems, as they are a subset of innovation ecosystems. Returning to the analogy of entrepreneurial ecosystems, which stems from a biological perspective, a few parallels can be drawn to strengthen the argument that it is necessary to understand value-creation. To create a symbiotic environment (ecosystem), firms need to be provided with the right 'nutrients' (tangible and intangible assets, and networking activities) through an authority structure (an intermediary) [6], [10], [19], [20].

Innovation intermediaries are actors who facilitate, configure, and broker opportunities and spaces for the creation and appropriation of products or services [21]. These three roles are the context for the analysis of the role of intermediaries in this study. An open innovation intermediary is an agent who disseminates the "the use of purposive inflows and outflows of knowledge to accelerate internal innovation, and expand the markets for external use of innovation, respectively" [3]. The intermediary uses platforms to bridge the gap between solution seekers and solution providers, thus enhancing the successful appropriation of open innovation by actors in the ecosystem [18].

With entrepreneurship, open innovation is something that can enhance the assets that entrepreneurial firms lack to be innovative and to create a sustainable competitive advantage over time [22]. Intermediaries are important in highly unpredictable environments, as they may reduce uncertainty and asymmetry between industry actors [21], [23]. Thus an intermediary can assist in the successful implementation of open innovation by a firm in the ecosystem through minimising the level of risk that can be incurred during the process of obtaining, integrating, and commercialising external innovations between the firm and the collaborators in the ecosystem [24]. In this case, ecosystem failure or stagnation is attributed to a lack of coordination among participants [19], [25], as innovation is considered to be a collaborative process. Intermediations are no longer bilateral, and in fact are becoming even more complex, as they are now part of complex systems [23]. This implies that looking at the intermediation process in ecosystems also offers a holistic approach to the mediation literature. The content, context, and process of open innovation (OI) is still a major gap in the research; so understanding OI intermediaries reinforces that logic [4]. Therefore, in an entrepreneurial ecosystem, the questions arise: What functions does an open innovation intermediary offer? Why should organisations consider using open innovation intermediaries? And what challenges arise from using these intermediaries [17]?

\subsection{Incubators as innovation intermediaries}

Incubators have moved from being just places of collaboration to becoming service providers. Thus, instead of merely playing a passive role, incubators have become part of the value-creation process of their inhabitants through proactive interaction and providing relevant services [26]. As a high level of tacit knowledge is exchanged in and around the incubator, effectively managing such interactions is a process proposed by the concept of 'open innovation', which needs levels of openness [27]. Over and above success rates in occupancy rates, the incubator has to figure out ways to offer a customised service that not only enhances the survival of a firm, but also contributes to the evolution and growth of the ecosystem.

\subsection{Interaction and the core pillars of entrepreneurial ecosystems}

In this study, the interaction processes in the entrepreneurial ecosystem are mapped according to the open innovation model proposed by Chesbrough [27], and simplified by Dahlander and Gann in their critique of open innovation [28], [29]. The feasibility - or the very existence - of the model for entrepreneurial firms is tested, as they are the primary beneficiary of entrepreneurial ecosystems, and are on the lookout for much-needed resources.

The literature base for this study is summarised in Figure 1. It shows the different streams in the literature, starting from the various 'pillars' of an ecosystem described by Isenberg [11]. These are accessible markets, human capital, funding, supports, culture, and policy. We look at how these pillars are translated to the actors and firms in the ecosystem via the incubator, using the open innovation framework. 


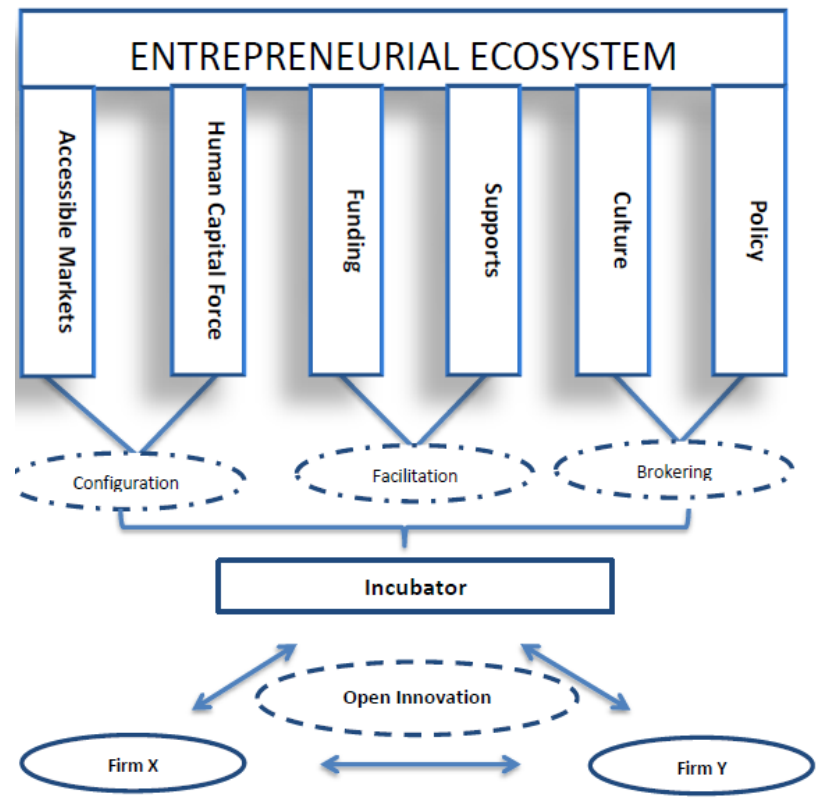

Figure 1: Literature frameworks and linkages

\section{RESEARCH METHODOLOGY}

\subsection{Research approach}

The study was undertaken as both an exploratory and a descriptive case study. Descriptive research explains an existing phenomenon; exploratory research aims seeks better insight into a topic [30]; and a case study offers a holistic approach to ascertaining why things occur in a certain way [31]. The concepts of 'intermediation' and 'open innovation', particularly with regard to entrepreneurial firms in an entrepreneurial ecosystem, need further exploration [6], [32]. Ten semi-structured indepth interviews were conducted, using an interview guide based on Table 1. Data was collected to identify the role of the intermediary and the firm interactions using open innovation metrics to describe the activities of interaction with the firm.

Table 1: Interview guide categories

\begin{tabular}{|l|ll|}
\hline \multicolumn{1}{|c|}{ Interview guide sections } & & \multicolumn{1}{c|}{ Sub-categories } \\
\hline $\begin{array}{l}\text { Role of the incubator } \\
\text { (Incubator and value-creation) }\end{array}$ & $\bullet$ & $\begin{array}{l}\text { Type of services/assistance offered (mediation role) } \\
\text { Interaction with the firms }\end{array}$ \\
\hline $\begin{array}{l}\text { Firm interaction } \\
\text { (Firm and value-creation) }\end{array}$ & $\bullet$ & $\begin{array}{l}\text { Types of interactions undertaken by the firm (open } \\
\text { innovation context) }\end{array}$ \\
\hline $\begin{array}{l}\text { Value addition to firms and } \\
\text { incubator }\end{array}$ & $\bullet$ & Observation of the entrepreneurial ecosystem actors \\
\hline
\end{tabular}

The interviews were conducted with the entrepreneurial firms and incubator management profiled in Table 2.

\subsection{Ecosystem case description}

The Oslo Cancer Cluster (OCC) incubator is situated within the Oslo Cancer Cluster, which has more than 70 members that service the oncology value chain of both Norway and Northern Europe. The incubator is unique in that the main tenants are service providers for the start-up firms; the startups themselves are in the minority. This case was selected for its unique qualities [33], [34]. 
Table 2: Interviewees

\begin{tabular}{|l|l|}
\hline Interviewee & Status \\
\hline Entrepreneurial firm 1, 2 and 3 & Inside incubator \\
\hline Entrepreneurial firm 4 and 5 & Inside incubator \\
\hline Entrepreneurial firm 6 & Considering incubation \\
\hline Investor firm & Inside incubator \\
\hline Incubator manager & $\begin{array}{l}\text { Inside incubator - focuses on incubator, engages with } \\
\text { cluster }\end{array}$ \\
\hline Cluster manager & $\begin{array}{l}\text { Inside incubator - focuses on cluster, engages with } \\
\text { incubator }\end{array}$ \\
\hline Head of marketing of cluster & Inside incubator - works with both cluster and incubator \\
\hline
\end{tabular}

The interviews reflected important aspects of ecosystem design. These have been arranged in to major categories: incubator management, and entrepreneurial firms. They are each discussed below.

\subsection{Incubator management}

The services that the incubator offers the entrepreneurs and the ecosystem are summarised in Table 3. Management mainly reflected on how the incubator was leaning towards a facilitation role as it fostered collaboration through services linked with office space, access to laboratories, and networking opportunities.

Table 3: Management overview of incubator and value-creation

\begin{tabular}{|c|c|c|}
\hline Intermediary role & To firm & To ecosystem \\
\hline Configuration role & $\begin{array}{l}\text { - Offers follow-up activities } \\
\text { - } \quad \text { Competence management }\end{array}$ & $\begin{array}{l}\text { - Part of national programmes on } \\
\text { cluster excellence } \\
\text { - } \quad \text { Provides companies that are } \\
\text { interested with international links }\end{array}$ \\
\hline Facilitation role & $\begin{array}{ll}\text { - } & \text { Offices } \\
\text { - } & \text { Meeting facilities, shared } \\
& \text { physical space } \\
\text { - } & \text { Easier access to funding } \\
\text { - } & \text { Laboratories } \\
\text { - } & \text { Special incubating seminars }\end{array}$ & $\begin{array}{l}\text { - } \\
\text { - } \quad \text { Invitations to exhibit at international } \\
\text { conferences } \\
\text { - Offers meeting space and interactions }\end{array}$ \\
\hline Brokering role & $\begin{array}{l}\text { Invest in service providers } \\
\text { that assist companies } \\
\text { Lobby for actors who aid } \\
\text { start-ups } \\
\text { - Assists companies to } \\
\text { commercialise }\end{array}$ & $\begin{array}{l}\text { Provides links to certain themes and } \\
\text { competencies in the cluster }\end{array}$ \\
\hline
\end{tabular}

With regard to interactions in the ecosystem, activities with which the incubator has assisted are summarised in Table 4. The interactions are of a more non-commercial nature, as the assumption is that collaboration is intense because firms are located close to one another, allowing negotiations and discussions to take place faster and to be less cumbersome. There is a generally high level of openness because the intellectual property rights of the technologies are in place, and because a technology transfer office and a legal entity are present among the service providers in the incubator.

\subsection{Entrepreneurial firms}

The tasks aligned with the intermediary roles that the incubator plays between the ecosystem and the firms are depicted in Table 5 . The prominent services that the incubator offers focus on brokering and facilitation. This encompasses complementary assets, such as the use of facilities at a nominal cost, and connecting entrepreneurial firms with the ecosystem, mainly through networking activities. With the growth of the firms and the evolution of the ecosystem, the entrepreneurial firms were calling for more customised service-oriented and one-to-one interactions as a service that the incubator could offer. 
Table 4: Management perspectives of firm and actor interaction in incubator

\begin{tabular}{|l|l|l|}
\hline $\begin{array}{l}\text { Open innovation } \\
\text { processes }\end{array}$ & Inbound innovation & Outbound innovation \\
\hline Commercial & $\begin{array}{l}\text { Acquiring: } \\
\text { Merging of companies }\end{array}$ & $\begin{array}{l}\text { Selling: } \\
\text { Licensing } \\
\text { Patent protected (not much activity) }\end{array}$ \\
\hline Non-commercial & $\begin{array}{l}\text { Sourcing: } \\
\text { Informal networking } \\
\text { Merging of industries - } \\
\text { e.g., EU collaboration } \\
\text { project combining IT } \\
\text { and biotech industries }\end{array}$ & \begin{tabular}{l} 
Combination therapies \\
\hline
\end{tabular} \\
\hline
\end{tabular}

Table 5: Entrepreneurial firms' view of Incubator roles

\begin{tabular}{|c|c|c|}
\hline Intermediary role & To firms & To ecosystem \\
\hline Configuration role & $\begin{array}{l}\text { - } \\
\text { - } \text { Access to legal team } \\
\text { - } \\
\text { - } \text { Access to funding } \\
\text { Discounted services from } \\
\text { service providers - e.g., patent } \\
\text { search }\end{array}$ & $\begin{array}{l}\text { - } \text { Grant-writers } \\
\text { - } \quad \text { Easier access to data and } \\
\text { publications that are expensive } \\
\text { - Access to other oncology companies }\end{array}$ \\
\hline Facilitation role & $\begin{array}{l}\text { - Offices and facilities } \\
\text { - } \quad \text { Allow companies to use } \\
\text { facilities for free } \\
\text { - Closer to oncology focal } \\
\text { companies } \\
\text { - } \text { Laboratory facilities } \\
\text { - } \text { Coffee station meeting area } \\
\text { being at same location }\end{array}$ & $\begin{array}{l}\text { - Interactions with other cluster } \\
\text { members }\end{array}$ \\
\hline Brokering role & $\begin{array}{l}\text { - } \text { Assisted with contacts } \\
\text { - Built credibility with potential } \\
\text { investors } \\
\text { - Build credibility with } \\
\text { prospective employees } \\
\text { - Close to research base, } \\
\text { technology, and staff } \\
\text { - Company presentation from } \\
\text { service providers } \\
\text { - Assistance in showcasing } \\
\text { company }\end{array}$ & $\begin{array}{l}\text { - Organise bio-conferences } \\
\text { - Networking and knowledge meet-ups } \\
\text { - Social football } \\
\text { - Partnering meetings } \\
\text { - Contact with companies that fit } \\
\text { company portfolio } \\
\text { - Offer marketing services }\end{array}$ \\
\hline
\end{tabular}

Though not formally acknowledging that they undertake activities related to open innovation, Table 6 shows that the firms do use the model in their interactions. They accept knowledge flows from external actors (inbound innovation), and share expertise or resources with external partners (outbound innovation). This is done commercially, where they make direct profits, or noncommercially, bringing intangible benefits to the firms. The incubator is seen to have enhanced and formalised their interactions.

\subsection{Value co-creation aspects for the entrepreneurs}

The value created by being a formal member of the incubator and ecosystem has come in various shapes and forms for the inhabitants. First, being part of the ecosystem has increased the firms' credibility in the eyes of investors, and increased their attractiveness to potential employees. Entrepreneurial firms typically find it difficult to attract experienced professionals; but this is eased when the firm shows its interconnectedness. Second, ease of access to elements such as clinical trial data or potential collaborators is an intangible asset that drastically reduces the development time of potential solutions and the costs for entrepreneurs. Due to the constant interaction between companies in the ecosystem, challenges facing companies tend to affect the whole ecosystem; so the firms and actors quickly discuss how to tackle the challenges together. Such an arrangement has also enabled the firms to take an active role in policy formulation, amendment, and regulation. Figure 2 highlights the key aspects that the firms currently require from the incubator and the ecosystem. 
Table 6: Entrepreneurial firms' perspectives of firm and actor interaction in incubator

\begin{tabular}{|c|c|c|}
\hline $\begin{array}{l}\text { Open innovation } \\
\text { processes }\end{array}$ & Inbound innovation & Outbound innovation \\
\hline Commercial & $\begin{array}{l}\text { Acquiring: } \\
\text { - Joint venture } \\
\text { activities } \\
\text { - Spin-offs } \\
\text { - Participation in } \\
\text { collaborative calls } \\
\text { - HR interchange } \\
\end{array}$ & $\begin{array}{l}\text { Selling: } \\
\text { - Licensing } \\
\text { - Assistance with technological legal issues }\end{array}$ \\
\hline Non-commercial & $\begin{array}{l}\text { Sourcing: } \\
\text { - Informal networking - } \\
\text { e.g., lunches } \\
\text { - Workshops with } \\
\text { service providers } \\
\text { - Sourcing information } \\
\text { from technology } \\
\text { transfer offices, R\&D }\end{array}$ & $\begin{array}{l}\text { Revealing: } \\
\text { - CEO five-minute pitches } \\
\text { - Company presentations } \\
\text { - Bio-conferences } \\
\text { - Combination therapies } \\
\text { - Participation in preferences for incubator } \\
\text { - } \text { environment } \\
\text { Sharing laboratory }\end{array}$ \\
\hline
\end{tabular}

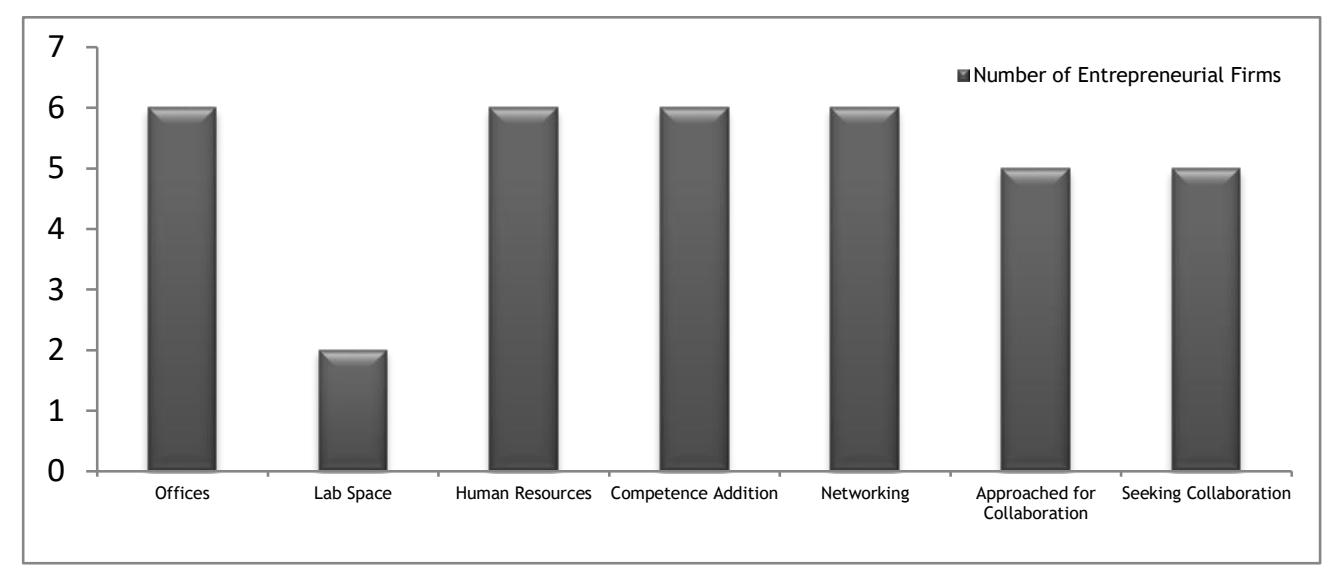

Figure 2: Summary of incubator resources required by firms

This section will interpret the results obtained from the entrepreneurs. It aims to provide relevant answers to the questions posed in the introductory section of the paper.

Sub-question 1: Is intermediation necessary in an entrepreneurial ecosystem?

The lack of any mention of 'intermediation' in most EES studies tends to suggest that, just by being part of the ecosystem, firms will automatically interact. This has been found not to be the case in this study. The incubator provides a forum to foster discussions and collaborations at a faster pace, aligning with the perception that value co-creation is more likely to occur when an authoritative structure is in place in the ecosystem [6], [15]. Furthermore, the success and value created for the individual firms translates into value for the incubator and the ecosystem. Through the incubator's successful intermediation, the firms survive and produce more tangible results; and these are relayed as a value proposition to any potential entrepreneurial firms that would like to join the ecosystem. This shows that there is a need for an intermediary to undertake task coordination and membership in line with the strategic direction of the ecosystem's evolution.

Sub-question 2: What intermediary role is of importance to the start-ups to promote value-creation in an entrepreneurial ecosystem?

As the ecosystem evolves and entrepreneurial firms grow, different mediation roles are required for effective value-creation. In their infancy, the firms favour a facilitation role - such as working spaces - in order to cut costs. However, during the growth stage, the need is to employ more staff, to build 
a culture, or even to extend the product line [7]. This stage requires the intermediary to configure and broker services and to be more proactive. Because the firms will be at different levels of growth, proactively customising service will be important.

Interestingly, intermediary roles are affected by the industry with which the firm is aligned. Even though entrepreneurial ecosystems are not mainly aligned with an industry's particular focus, but are more interested in the constraints that entrepreneurial firms face in the process of creating value [7], this study offers a different perspective. The industry of which the firm is part plays an integral role in how mediation occurs. In this study, having a large addressable market and sound intellectual property rights makes open innovation processes much easier to integrate, thus affecting the services required from the intermediary.

Sub-question 3: What interaction processes aid value-creation between actors and the intermediary in an entrepreneurial ecosystem?

The OCC is currently in its infancy, so it is still looking at how to tailor-make services; its main focus at the moment is on space. Nevertheless, in the process of conceptualising the incubator, there was a constant interaction with ecosystem actors. This has built a sense of loyalty to the incubator; and this level of trust promotes more openness in the ecosystem, which is essential for value to be created [35]. In this case, due to a shared space, firms find it easy to share ideas and advice [35], [36].

\section{IMPLICATIONS OF THE RESEARCH}

This study raises a number of implications for entrepreneurial firms in resource-constrained areas.

Ecosystems management: Employing open innovation in ecosystems development opens up the boundaries of the ecosystem. By offering consultative forums to current and prospective entrepreneurs and potential stakeholders, it makes trust, loyalty, and resource management relatively easier. It is of paramount importance to understand the industry dynamics in order to serve the ecosystem better. Moreover, with firms now more geared towards service provision [37], cross-industry collaborations are more common. So ecosystem management has to consider that and how the ecosystem can link up with other systems, regionally and globally. The government can play a central role by being a driver of intermediary organisations that enhance the livelihood and mandate of sound service delivery for citizens. This could facilitate a situation where the focal point of ecosystems might not only be about the number of firms making profits, but also about how the ecosystem can contribute to sustainable developmental goals and service delivery in the country.

Intermediaries (Incubators): For intermediaries to contribute effectively to the ecosystem, being proactive is important, as the ecosystem becomes more complex over time [8], [19], [38]. It is important to have open forms of communication with the ecosystem actors. Intermediaries need to be proactive in ensuring that they offer relevant services. Additionally, as intermediaries can be any focal agent or body, it is not essential to invest in building a physical space in the name of having an intermediary (incubator). As noted before, close proximity does not guarantee that firms will collaborate. Instead of building new intermediaries, use can be made of existing institutions such as universities or research organisations that work with ideas and entrepreneurial development.

Entrepreneurial firms: The full benefits of ecosystem engagement and value-creation for a firm only occurs when it decides to build a culture of collaboration and information-sharing. Although such actions start off as non-commercial and are unlikely to be monetised, they eventually translate into commercial benefits as tangible resources. Firms should embrace the concept of affordable loss that is, being willing to accommodate risk and share their innovations with the ecosystem, as this could result in unexpected and favourable results [39].

\subsection{Limitations of the research}

This study was undertaken in Norway, and focused on the oncology industry. It is expected that the findings will be slightly different in different regional and industry contexts. Future work could include a longitudinal study that assesses how the intermediary role mutates as the ecosystems evolve and support the growth of entrepreneurial firms. 


\section{REFERENCES}

[1] L. Fang, “Do Clusters Encourage Innovation? A Meta-analysis,” J. Plan. Lit., vol. 30, no. 3, pp. 239-260, Aug. 2015.

[2] M. E. Porter and C. van der Linde, "Toward a New Conception of the Environment-Competitiveness Relationship,” J. Econ. Perspect., vol. 9, no. 4, pp. 97-118, Oct. 1995.

[3] H. Chesbrough, W. Vanhaverbeke, and J. West, Open Innovation: Researching a New Paradigm. OUP Oxford, 2006.

[4] E. K. R. E. Huizingh, “Open innovation: State of the art and future perspectives," Technovation, vol. 31, no. 1, pp. 2-9, Jan. 2011.

[5] S. D. Sarasvathy, "Causation and Effectuation: Toward a Theoretical Shift from Economic Inevitability to Entrepreneurial Contingency," Acad. Manage. Rev., vol. 26, no. 2, pp. 243-263, 2001.

[6] E. Autio and L. D. W. Thomas, "Innovation ecosystems : implications for innovation management?," Oxf. Handb. Innov. Manag., 2014.

[7] B. Spigel, "Developing and Governing Entrepreneurial Ecosystems," 2016, vol. 7, pp. 141-160.

[8] B. Spigel, "The Relational Organization of Entrepreneurial Ecosystems," Entrep. Theory Pract., p. n/a$\mathrm{n} / \mathrm{a}$, Jun. 2015.

[9] O. R. Spilling, "The entrepreneurial system: On entrepreneurship in the context of a mega-event," J. Bus. Res., vol. 36, no. 1, pp. 91-103, May 1996.

[10] B. Cohen, "Sustainable valley entrepreneurial ecosystems," Bus. Strategy Environ., vol. 15, no. 1, pp. 1 14, Jan. 2006.

[11] D. Isenberg, "The entrepreneurship ecosystem strategy as a new paradigm for economic policy: Principles for cultivating entrepreneurship," Present. Inst. Int. Eur. Aff., 2011.

[12] G. Zanello, X. Fu, P. Mohnen, and M. Ventresca, "The Creation and Diffusion of Innovation in Developing Countries: A Systematic Literature Review,” J. Econ. Surv., vol. 30, no. 5, pp. 884-912, Dec. 2016.

[13] C. Mason and R. Brown, "Entrepreneurial ecosystems and growth oriented entrepreneurship," Final Rep. OECD Paris, vol. 30, no. 1, pp. 77-102, 2014.

[14] Y. Motoyama and K. Knowlton, "Examining the connections within the startup ecosystem: A case study of st. louis," Entrep. Res. J., vol. 7, no. 1, 2017.

[15] L. Thomas and E. Autio, "Modeling the ecosystem: a meta-synthesis of ecosystem and related literatures," in DRUID 2012 Conference, Copenhagen (Denmark), 2012.

[16] Y. Motoyama and K. K. Watkins, "Examining the Connections within the Startup Ecosystem: A Case Study of St. Louis," SSRN Electron. J., 2014.

[17] T. Bailetti and D. Hudson, "Value Co-creation: Lessons from Lead to Win Ecosystem," Open Source Bus. Resour., no. December 2009, 2009.

[18] E. den Ouden, Innovation Design. London: Springer London, 2012.

[19] P. E. Auerswald, "Enabling Entrepreneurial Ecosystems," Social Science Research Network, Rochester, NY, SSRN Scholarly Paper ID 2508323, Oct. 2014.

[20] J. Suresh and R. Ramraj, "Entrepreneurial ecosystem: Case study on the influence of environmental factors on entrepreneurial success," Eur. J. Bus. Manag., vol. 4, no. 16, pp. 95-101, 2012.

[21] M. Agogué, A. Yström, and P. Le Masson, "RETHINKING THE ROLE OF INTERMEDIARIES AS AN ARCHITECT OF COLLECTIVE EXPLORATION AND CREATION OF KNOWLEDGE IN OPEN INNOVATION,” Int. J. Innov. Manag., vol. 17, no. 02, p. 1350007, Apr. 2013.

[22] U. Lichtenthaler, "Open Innovation in Practice: An Analysis of Strategic Approaches to Technology Transactions," IEEE Trans. Eng. Manag., vol. 55, no. 1, pp. 148-157, Feb. 2008.

[23] J. Howells, "Intermediation and the role of intermediaries in innovation," Res. Policy, vol. 35, no. 5, pp. 715-728, Jun. 2006.

[24] J. West and M. Bogers, "Leveraging External Sources of Innovation: A Review of Research on Open Innovation: Leveraging External Sources of Innovation," J. Prod. Innov. Manag., vol. 31, no. 4, pp. 814831, Jul. 2014.

[25] J. Stewart and S. Hyysalo, "INTERMEDIARIES, USERS AND SOCIAL LEARNING IN TECHNOLOGICAL INNOVATION,” Int. J. Innov. Manag., vol. 12, no. 03, pp. 295-325, Sep. 2008.

[26] H. Chesbrough, Open Services Innovation: Rethinking Your Business to Grow and Compete in a New Era. John Wiley \& Sons., 2010.

[27] P. Ritala and A. Tidström, "Untangling the value-creation and value-appropriation elements of coopetition strategy: A longitudinal analysis on the firm and relational levels," Scand. J. Manag., vol. 30, no. 4, pp. 498-515, Dec. 2014.

[28] H. W. Chesbrough, Open Innovation: The New Imperative for Creating And Profiting from Technology, First Trade Paper Edition edition. Harvard Business Review Press, 2005.

[29] L. Dahlander and D. M. Gann, “How open is innovation?," Res. Policy, vol. 39, no. 6, pp. 699-709, Jul. 2010.

[30] J. Wilson, Essentials of Business Research: A Guide to Doing Your Research Project. SAGE Publications, 2010.

[31] R. K. Yin, Case Study Research: Design and Methods. SAGE Publications, 2009.

[32] O. Gassmann, E. Enkel, and H. Chesbrough, "The future of open innovation," RD Manag., vol. 40, no. 3, pp. 213-221, Feb. 2010.

[33] K. M. Eisenhardt, "Building Theories from Case Study Research," Acad. Manage. Rev., vol. 14, no. 4, pp. 532-550, Oct. 1989. 
[34] R. K. Yin, Case Study Research: Design and Methods. SAGE, 2009.

[35] L. D. W. Thomas and E. Autio, “The Fifth Facet: The Ecosystem as an Organizational Field," Acad. Manag. Proc., vol. 2014, no. 1, pp. 10306-10306, Jan. 2014.

[36] M. P. Rice, “Co-production of business assistance in business incubators: an exploratory study," J. Bus. Ventur., vol. 17, no. 2, pp. 163-187, Mar. 2002.

[37] H. Chesbrough, Open Services Innovation: Rethinking Your Business to Grow and Compete in a New Era. Wiley, 2011.

[38] B. Spigel, "Developing and Governing Entrepreneurial Ecosystems," presented at the 8th Annual International Conference for Entrepreneurship, Innovation, and Regional Development, 2015.

[39] R. Adner and R. Kapoor, "Value creation in innovation ecosystems: how the structure of technological interdependence affects firm performance in new technology generations," Strateg. Manag. J., vol. 31, no. 3, pp. 306-333, Mar. 2010. 